\title{
Structure and Trends of Financial Development and Sectoral Growth in Ethiopia
}

\author{
Tekilu Tadesse \\ Lecturer, department of economics, Jimma University, Ethiopia
}

\begin{abstract}
Ethiopian economy had passed through different regimes and, hence economic policies had formulated differently. As a result, national economic policies were set in line with the respective regime's political ideology as policies are directed with the intention of achieving a wide range of macroeconomic goals. Throughout all regimes, the major financial institutions operating in Ethiopia are banks, insurance companies, and microfinance institutions and the financial sector of the country shows a slightly on the way of growth but the performance of the financial sector of Ethiopia as compared to other middle-income African countries shows the need for more improvement which show still weak financial system which manifested in high government regulation and dominance of the government-owned commercial bank in terms of holding assets, savings mobilization, and loans disbursement. Following different economic policies set by different regimes, on average, the service sector has contributed increasingly and agricultural sector decreasingly contribute to economic growth while until implementation of Growth and Transformation plan I, industry sector showed a slow trend in contribution to economic growth In line with surprising economic growth registered last one decades, the financial system in Ethiopia has also improved following rapid growth in the number of participating institutions including the scope and services rendered in which the system comprises the regulatory authorities, banks, non-bank financial institutions.
\end{abstract}

Keywords: financial development, sectoral growth, Private credit to sectors, Ethiopia

DOI: $10.7176 / \mathrm{DCS} / 10-8-01$

Publication date:August $31^{\text {st }} 2020$

\section{Introduction}

Analyzing structure and trends of financial development and sectoral output growth in a given country is crucial because it provides useful information on economic phenomena that the government and concerned bodies need to control relevant variables in order to attain the desired level of the macroeconomic objectives such as economic growth (Miftah, 2013).

In Ethiopia economic system including financial institution has become market-oriented in 1992 after the collapse of socialism economic system and has undergone financial reforms called liberalization through gradualism (Alemayehu, 2006; Murty et al., 2012). After the policies reform, Ethiopia has been experiencing strong economic growth compared to early years; the major financial institutions operating in Ethiopia are banks, insurance companies, and microfinance institutions and the financial sector of the country shows a slightly on the way of growth but the performance of the financial sector of Ethiopia as compared to other middle-income African countries shows the need for more improvement (Fozia, 2014). This clearly show that there is still weak financial system which manifested in high government regulation and dominance of the government-owned commercial bank in terms of holding assets, savings mobilization, and loans disbursement. In sub-Saharan countries in which Ethiopia is inclusive, the national saving is very low and insufficient to finance the development which necessitating financial sector development and attraction of foreign direct investment (Roman, 2012).

Moreover, Ethiopia's financial sector is infant stage and is highly dominated by the banking system. Ethiopia has also expreienced the non-existance of capital market and undergound informal investment in shares of private companies. In addition to missing market of capital including stock and equity market, money markets are at infant stage and there is only a thin primary market for treasury bills and weak inter-bank money market. There are only government issued bonds available in Ethiopia. Despite of supply of the banking service which is growing from year to year, it has not yet increased the outreach of the banking system at large in which large populations are not served well. This is an implication that Ethiopia still characterized by under-banked country in the world (Kiyota et al, 2007 and Roman, 2012).

Development of the financial sector has a long history and categorized as banking and non-banking institutions which consists of commercial banks, development banks, specialized financial institutions, cooperatives, insurance companies, etc. However, the organizational structure, management, and ownership of these financial institutions as well as their performance have been varying across the three regimes (Roman, 2012).

Although some success registered in financial sector development through shifting the direction of the flow financial resources (mainly credit) from public enterprises to the private sector during post reform regime, the economic reforms have failed to make linkage financial sector with dominant sector mainly the agricultural sector to be more attractive and suitable for long term investments through the use of financial sector. As compared to industry and service sector, the share of agricultural sector in the total credit disbursed by the banks has been 
marginal which will have little impact on long-term investment and transformation of agriculture for commercalization. However, agricultural sector's actual and expected contribution to the economy has significantly large next to service sector (Alemayehu, 2006).

When looking the structural transformation of the sector, Ethiopia has enjoyed strong economic performance since the mid-2000s which has helped turn Ethiopia into one of the fastest growing non-oil producing economies on the continent, with average annual growth rates above 11 percent between 2004 and 2008 - driven mainly by the agriculture and services sectors. Currently, Ethiopia has recorded a rapid economic performance of 10.2 percent in 2015; continuing the double-digit growth trend with the broad contribution of all sectors in which industry grew by 21.6 percent, services sector by 10.2 percent and agriculture by 6.4 percent. Regarding the share in GDP, agriculture, industry, and service sector share of GDP were 38.8 percent, 15.2 percent and 46.7 percent, as well as their contribution to annual growth, were 3.0 percent, 4.7 percent and 2.5 percent respectively revealing that there is gradual structural transformation (NBE, 2016).

In line with surprising economic growth, the financial system in Ethiopia has also improved following rapid growth in the number of participating institutions including the scope and services rendered in which the system comprises the regulatory authorities, banks, non-bank financial institutions with non-existent capita markets (Dejene, 2016). Therefore, analyzing the structure and trend of financial sector development towards supporting the output growth in agriculture, industry, and service sectors were the main concern of the study.

\section{Structure and Trends of Financial Development}

Structure of financial sector development in Ethiopia

The organizational structure, management, and ownership of these financial institutions as well as their performance have been changing under the three regimes which are overviewed as follows.

\section{Imperial Period}

In Ethiopia history, Banking started in 1905, with the establishment of the Bank of Abyssinia that was owned by the Ethiopian government in partnership with the National Bank of Egypt then under British rule. But a modern well-structured banking system started in 1942 after the Italian departure, established by emperor charter as state bank of Ethiopia which had dual function of a central and commercial bank until 1963 and reorganized as two financial institution namely national bank of Ethiopia acting as central bank of Ethiopia and commercial bank of Ethiopia in which commercial bank of Ethiopia aimed at to control overall activities of banking business with public mainly to mobilize saving in the country. Other than mentioned financial institution, from the 1960s onwards, there were around eight institutions that involved in saving mobilization in the country (Assefa, 2003). The government had implemented five years development plan which includes major intervention in the allocation of financial resources towards fostering national overall development, basically bank credit allocation to priorities sectors set by the plan such as agricultural sector as leading sector followed by mining and manufacturing as targeted sectors.

In development plan, the government intervention was manifested on credit allocation and interest rate discrimination between productive investment project based on the priority set by development plan and current transaction with irrespective public and private sector ownership in favoring investment. There was no credit access and interest rate discrimination among the private and public sector in which private sectors including foreign investors played important role in investing productive economic activities along with public sector.

According to Assefa (2003), the development plan efforts to support agriculture and small farmers through credit were not a success for a number of reasons including the collateral requirement involved, the landlord-tenant relationship and the like made the credit allocation to be ineffective in prioritized sector and diversion of loans to non-agricultural uses as well. As result of the fungibility problem of the funds, most of the loan was allocated towards industrial sector which observed $58 \%$ of the total loan while agriculture had a negligible amount of loan left over despite of different approaches geared to raise production in agriculture.

\section{Derg period (pre-reform period)}

During this period, previously private-owned financial institutions including three commercial banks, thirteen insurance companies and two non-bank financial intermediaries were nationalized on January $1975^{1}$. The government reorganized the financial system and formed one commercial bank (CBE), a national bank (NBE), two specialized banks (AIB \& HSB) and one insurance company (EIC). AIB was mainly responsible for financing agricultural and industrial projects with medium and long growth period, while HSB used to lend for the construction of residential and commercial buildings. CBE was engaged in trade and other short-term financing

\footnotetext{
2 The commercial banks were Addis Ababa Bank, Banco di Napoli and Banco di Roma. The insurance companies were African Solidarity, Ethio-American life, Blue Nile, Ethiopian General, Imperial, Afro-Continental, Pan-African, Union, Ras, and Ethiopian Life and Rasi. The non-bank financial intermediaries were the Imperial Saving and Home Ownership Public Association and the Mortgage Corporation (Befekadu, 1995).
} 
activities while EIC was the only insurance firm responsible for the provision of all types of insurance services. The National Bank of Ethiopia (NBE) was granted the power to provide loan and advances to the government whenever revenue falls under expenditure. Moreover, the NBE was delegated to formulate the credit policy and determine the interest and exchange rate as well (Roman, 2012).

Moreover, one of the government regulations up on financial sector was fixing deposit and lending rates for prolonged period. The intervention of government was towards controlling financial sector through using a different financial instrument such as lowering the interest rate and discriminating the allocation of foreign exchange and credit. The allocation of foreign exchange was directed towards financing the fiscal deficit under the shortage of revenue as well as domestic credit was also in accordance with central government planning. The huge amount of loan and advance allocated to the centralized government from the NBE which raised its limitation to 70 percent from 15 percent in 1963 (MEDaC, 1999) cited in Roman (2012). Similarly, the share of domestic credit of the central government alone (excluding credit to public enterprises and state farmers) which was only $11 \%$ in 1974 averaged 47\% between 1975 and 1990, and 50\% between 1980 and 1990 (Assefa, 2003). The private sector was highly neglected. This implies that banking system geared towards government motive rather than boosting the productive sectors. On another hand, CBE was the dominated more than $90 \%$ of the total deposits mobilized in the country. The any credit policy and foreign exchange earnings framework were under the control of NBE in accordance with strengthening the power of the socialized sector (Alemayehu, 2006).

When come to sectoral bank credit allocation, $55 \%$ of all commercial bank credit allocated to imports and domestic trade and services while remaining agriculture and industry absorbed only $6 \%$ and $13 \%$ of the commercial credit in 1988 respectively (Wondaferahu, 2010). Loans and advances by financial institutions over the ten year period between 1981 and 1990 show that on average the government sector absorbed 37.4 percent of the total, while $51.3 \%$ went to public enterprises while the private sector's share was only $9 \%$ of the total loans and advances made by the banking system during the Derg regime (NBE, 2016).

Overall, the financial system in Ethiopia was highly repressed due to nationalizing private sector, regulated interest rate and saving and intervention on limiting the credit allocation so as to serve the socialized sector which came up with inefficient and poor resources allocation towards public sector because banks have been enforced by the NBE to lend for non-viable investments in the public sector with low-interest rate. As result, large amount credit allocated to the public enterprises, especially state farms credit remained uncollected and banks system associated with low rate of growth of capital as well as reserves. Thus financial repression characterized by great distortions in the economy during this regime.

\section{Post-reform period}

With the overthrow of the Derg in 1991, the new government comes up with a new economic policy from socialized economic system to market-oriented economy. As result, financial liberalization in Ethiopia began in 1992. The strategy of government for financial development under liberalization rule is characterized by gradualism. This mean that one of the issues has been undertaken under the new government is allowing private participation on financial intermediaries through new entry of domestic private rather than immediate privatizing of state-owned institution which was applied in Mozambique (Addison and Alemayehu, 2001). Following proclamation number $84 / 94$ of the deregulation and liberalization of the financial sector, a number of private banks and insurance companies were established. For further development of the financial sector, gradual liberalizations of the interest rate, foreign exchange determination, and money market operation has been conducted as well (Roman,2012).

In 1992, the first step that has undertaken by the government in the exchange rate reform was devaluating the domestic currency from 2.07 Birr per the dollar to 5 Birr per the dollar in order to achieve economic recovery through promoting export and discourage imports. The auction- system basically worked alongside with the official (fixed) exchange rate which was introduced in 1993. The main attention made by government was exchanges reform and trade system so as to correct the major policy distortions of the Derg era, particularly the policy reform removed the disincentive to produce exportable inherent in the pre-1992 because of currency overvaluation (Addison and Alemayahu, 2001). Despite of policy reform, NBE supply of the foreign exchange through the auction-based exchange rate system was not in line with satisfying the demand of banks.

During the financial sector reforms, the mandate given to the NBE is to supervise and administer the commercial banks activities so as to operate within the general financial framework and introduce the competitive environment for banks and non-bank financial sector in order to encourage private sector involvement. According to Alemayehu (2006), the number of banks which were active before the 1974 revolution were only 9 with 113 branches altogether. However, there are 18 banks with 3197 branches of which 16 banks with 1,927 branches are private owned (NBE, 2016). Currently, about 34.4 percent of bank branches were in Addis Ababa and 60.5 percent of the total branches were private owned across the country as a result of a significant capital injection by the private banks (NBE, 2016). The expansion of banks plays a decisive role for the process of financial sector development in which the dynamic change of economy relies on the effective and efficient resource allocation 
made by baking industry (see appendix A).

The private banks establishment in the country gradually led to improved banking service such as longer banking service hours, ATMs, electronic banking and improved facilities (Roman, 2012).

Regarding distribution of banking service over the country, bank branch to total population ratio declined from $1: 126,258$ in $2008 / 09^{1}$ to $1: 28,932$ in $2015 / 16^{2}$ which shows significant improvement in term of accessing banking service across the country. This expansion in banks leads to a fall in population per branch and improved access to financial services in the country. On another hand, the non-banking sector though remains largely undeveloped, at the year of 2015/16 the number of insurance companies stood at 17 (1 public and 16 private) with their branches rising to 426 following the opening of new branches. Large concentration of insurance branches was in Addis Ababa which accounts about 53.5 percent and 83.6 percent of the total branches were private owned across the country. The total capital of insurance companies grew 25.3 percent to Birr 3.6 billion of which the share of private insurance companies was accounted 76.7 percent. Similarly, the number of micro-finance institutions remained at 35 while their total capital and total asset increased significantly by 23.5 and 20.0 percent and reached Birr 8.9 billion and Birr 36.7 billion, respectively. This significant improvement in private banks and non-bank financial sector is in line with fast-growing economic growth recorded in Ethiopia (NBE, 2016)(see also appendix $\mathrm{A}$ and $\mathrm{B})$.

The interbank foreign exchange and monetary market was established in 1998 through which the NBE issued directives so as to make the banking system to control over their foreign-exchange requirements more efficiently whereas money market framework enables banks and non-bank financial institutions can borrow and lend at market-determined rates which should reduce the existence of the excess liquidity in the banking system. However, the critical problem associated with the low performance of inter money market is a lack of collateral and presence of excess liquidity in the banking system due to a fear of risk in lending directly to private enterprises (Alemayehu,2006). Treasury bills market is the only regular primary market where securities are transacted on a fortnightly basis. Long-term securities are not widely traded except for the occasional issuance of government bonds to finance government expenditure. No secondary market for these securities exists (Roman, 2012).

\section{Trends of Financial Development Indicator}

To assess the trend of the financial sector development indicator, we used bank credit to three economic sectors as financial sector indicators to find the relationship between financial development and sector output growth. As result, the performance and the trend of bank credit to economic sectors in term growth and share of total credit in Ethiopia are discussed.

A sectoral based distribution of bank credit made by banking sector has important implication for sectoral output growth. For instance, providing a loan to productive sector accelerates the sectoral output growth while loan disbursement toward consumption sector caters the output growth.

The loan disbursement during Derg regime was characterized by serving state-based sector rather than prioritizing productive sector. Accordingly, there was declining trend of bank credit to agricultural sector from the year of 1979 to 1991 especially negative growth of agricultural bank credit recorded except for the year of 1980, 1984, 1986 and 1988. As the figure shows that there was also the persistent decline of agricultural sector bank credit share in total loan disbursement from 60 percent in the year of 1979 to $14 \%$ in 1983 and began to increase slightly to $31 \%$ share in 1988 . This implies that overall decreasing performance of bank credit share of the total loan during Derg regime in which lion's share of the credit belongs to public enterprise and cooperative operated by the government. This is the implication that most of the disbursed credit to stated owned enterprise and cooperatives remained uncollected which impeded further credit expansion. During the post-reform period, the liberalization of financial sector come up with encouraging the private sector in economic activities, the loan disbursement to agricultural sector has observed relatively positive growth from 1992 to 1999 with exception of negative growth recorded in 1994 and 1997. There is also successive declining performance observed from the year of 2000 to 2003 due the occurrence of drought. From the year onwards from 2004, the growth of the agricultural sector has been seen a negligible growth of bank credit towards agricultural sector except for the year of 2009 and 2013. Regarding total bank credit share of this sector, the largest share in total credit has observed in 2012 with a share of $25 \%$ and lowest share is $5.4 \%$ in 1994 during post-reform period. This implies that the low share of agricultural credit in total credit, as well as the poor growth of bank credit, is the implication of weak attention given to agricultural sector to promote commercialization of sector which is a part of GTP -2 by the current government.

\footnotetext{
${ }^{1}$ Taking total population as 80 million in 2008/09 as CSA estimation

${ }^{2}$ Total population is $92,205,000$ as CSA estimation for 2016
} 
Figure 1 growth of Bank credit allocation to Agriculture, industry and service sector

Sectoral specific Bank credit Growth

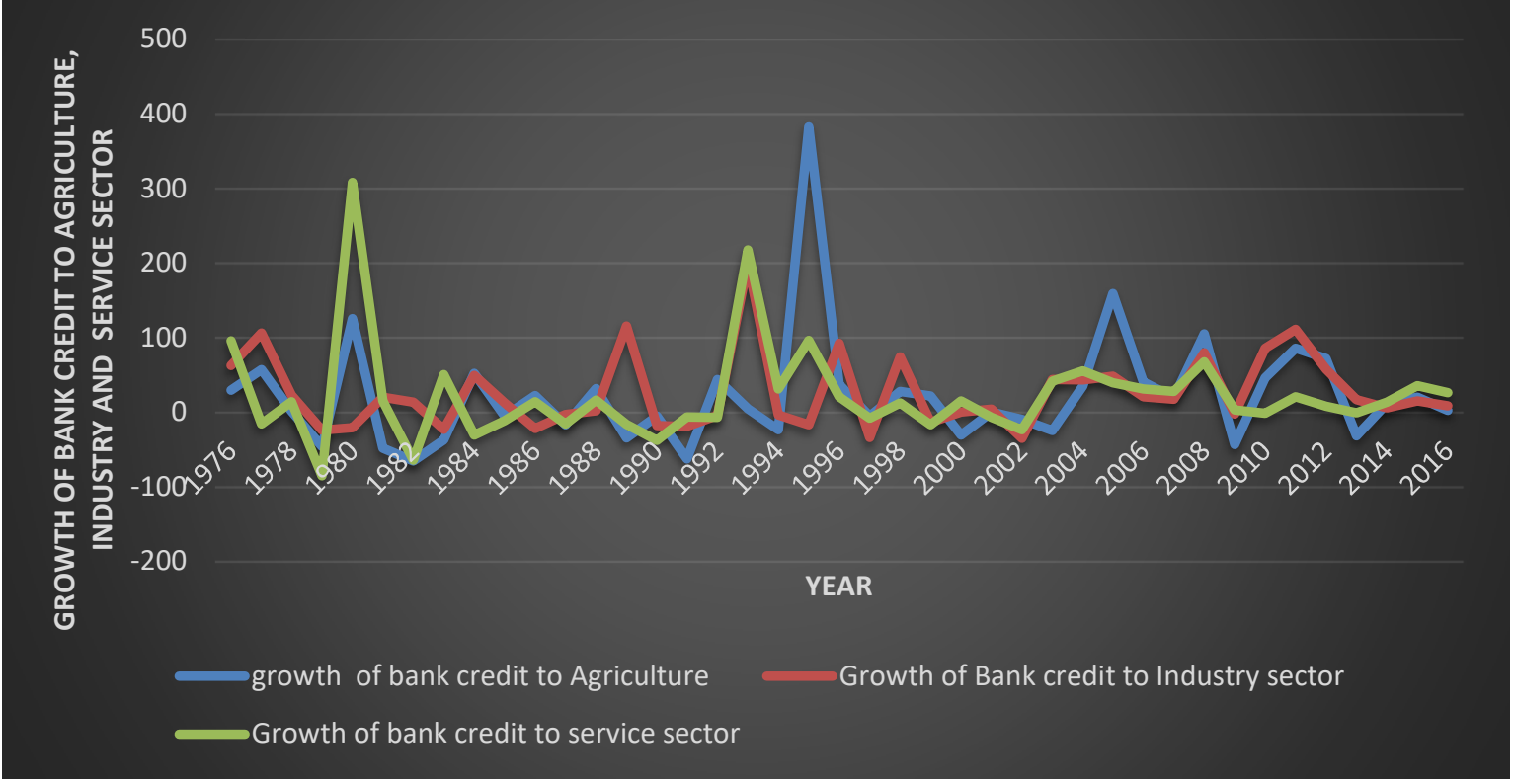

Source: author computation from national bank of Ethiopia abstracts, 2017

The commercial bank credit to the industry sector shares in a total loan under pre-reform with an average of $8.2 \%$. The maximum value was $19.7 \%$ in 1990 while the least value was $1.7 \%$ in 1980 as shown in figure 2 . This implies that there was an increasing trend in the share of bank credit to industry sector as compared to the agriculture sector. However, when we see from annual growth of industrial credit, there was negative growth observed in the year of 1980, 1983, 1986-87 and 1990 which indicates large fluctuation of industrial sector bank credit growth during the pre-reform period due to less attention given to this sector. Furthermore, industrial sector bank credit share in total loan under the post-reform period shows increasing trend from 1992 to 2002 with slight fluctuation in the year of 1995 and 1997 which was observed as a share of $8.1 \%$ and $8.7 \%$ to total credit respectively. With strong government encouragement to promote manufacturing sector for economy transformation through active private sector involvement, there is increasing trend in the share of bank credit to industry in total loan observed from the year 2003 onwards in which Ethiopia experienced fast economic growth. From the year starting from 2003, the Slight upward increasing trend is depicted with the average share in total bank credit of $17.2 \%$. The maximum value was $35.5 \%$ in 2014 while the least value was $8.7 \%$ in 1995 as shown in figure 4.2 .

The bank loan and advanced to the service sector share in total credit average $62 \%$ and the maximum value was $80.5 \%$ in 1979 while the least was $33.2 \%$ in 1983 during the pre-reform period. As depicted from the figure, there was upward and downward trend observed due to underdevelopment of financial sector under the regulation of socialized government and restriction imposed on the economic activities of the private sector. Similarly, even though high shares observed, the growth of service sector bank credit was slightly declined for overall pre-reform period except the year of 1983, 1986 and 1988. After the economic reform, however, bank credit to service sector began to increase due to increasing participation of the private sector. During post-reform period a large amount of loan and advance allocated to this sector with an average share of $66.7 \%$ and maximum credit share recorded is $78.5 \%$ in 2004 the least value was $45.3 \%$ in 2012. The share of total credit is shown declining trend after 2011 due to increasing share of industry sector. This implies that as compared to other sectors the service sector shares a large proportion of commercial bank credit in the Ethiopia economy. 
Figure 2: the share of agriculture, industry and service sectors credit to total bank credit

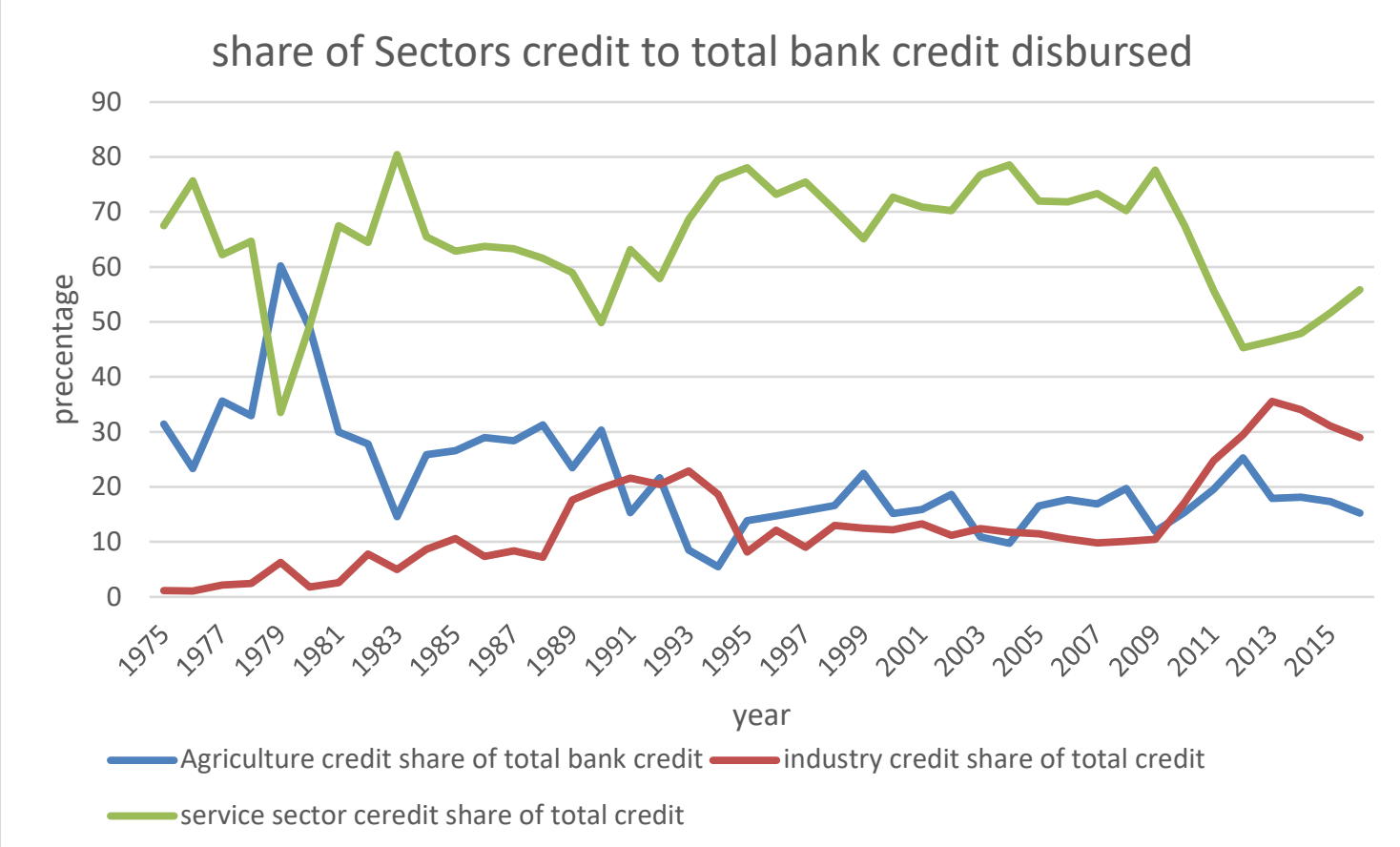

Source: author computation from national bank of Ethiopia abstract, 2016

Comparatively, using the average credit allocation to the sector, the service sector received the highest credit allocation in Ethiopia economy followed by the industrial sector while the agricultural sector received the least share of total credit during the study period.

Moreover, as shown in figure, About 29.0 percent of the loans went to industry followed by domestic trade (17 percent), housing and construction (16 percent), agriculture (15 percent) and international trade (11 percent) and others (12 percent) during the year of 2016 (see appendix J). This implies that increasing share of bank credit is allocated to industry in which government has given due attention for transformation of economy through working on industrial sector. However, the dominant sector has neglected the attention in making investment through credit expansion for which financial sector intended to link with other sector than agriculture.

Figure 3: Loans \& Advances by Economic Sectors in 2016

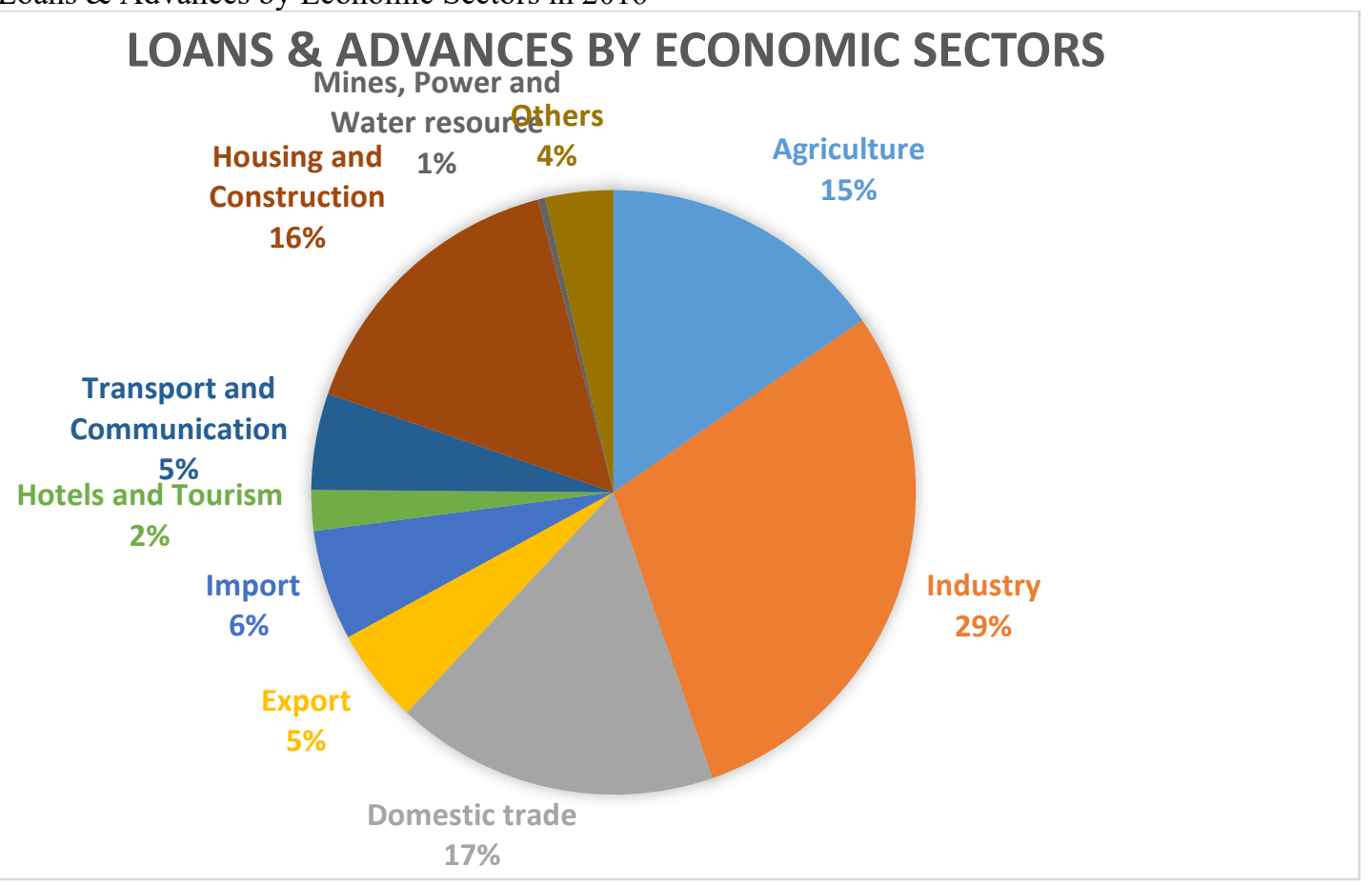

Source: author computation from national bank of Ethiopia abstracts, 2017 


\section{The trend of output growth at aggregate and sectoral level in Ethiopia}

Ethiopia has experienced tangible progress in key economic and social indicators and also known as one of Africa's fastest-growing economies, with near double-digit GDP growth over the past decade and huge infrastructural development since the early 2000s. Average annual real GDP growth increased from $2.5 \%$ during the 1980 s to over $10.7 \%$ in the period from $2003 / 04$ to $2015 / 16$. The country registered an average annual growth rate of $8.8 \%$ between 2000/01 and 2015/16, and as the population growth rate of 2.6\% implying real GDP per capita increased by about $6.9 \%$. Largest growth rate recorded during pre-economic reform was $13.1 \%$ in 1987 while least growth was $-8.7 \%$ in 1985 due to frequent drought and civil war along with distorted economic policy followed by the socialist government whereas there has been positive growth and fluctuation trend observed after the economic reform took place except for the year of 1998 and 2003 in which Ethiopia economy has challenged by external shocks such as famine and Eritrean war devastated the economic growth.

Figure 4. The growth rate of real GDP

\section{growth of realGDP}

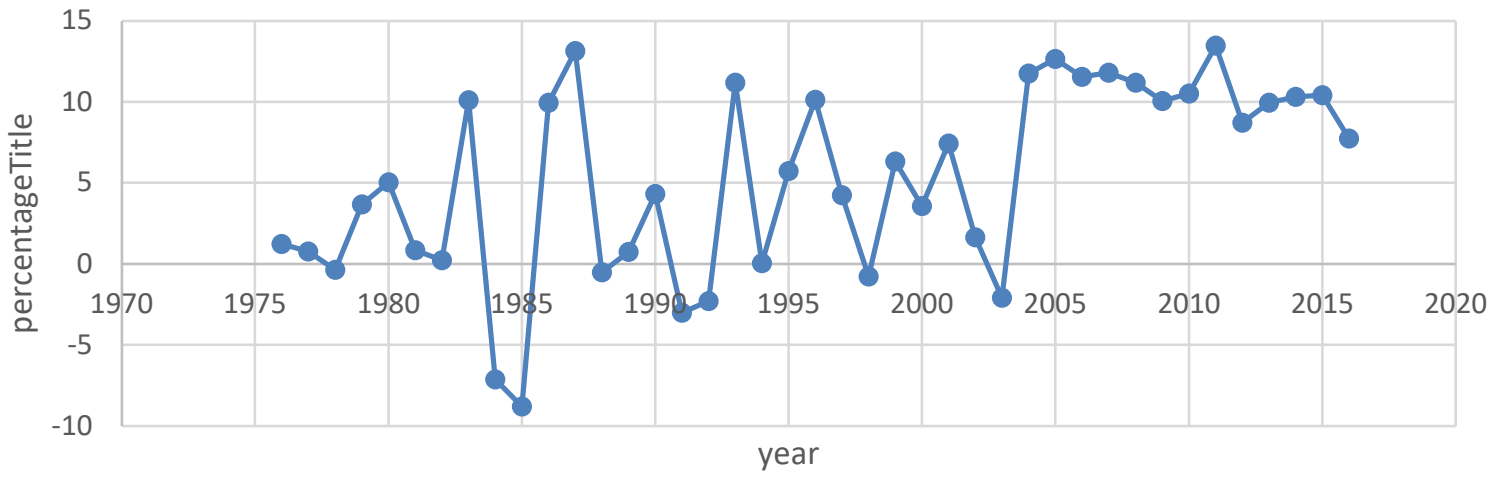

Source: author computation from national bank of Ethiopia abstracts and MOFEC data

Regarding the trend of agricultural growth as shown in above figure 4.4, the agricultural growth of Ethiopia, as measured by the real agricultural GDP as shown in Figure 4.4, is full of ups and downs fluctuating from positive to negative growth. In between 1975 and 1992, the real GDP growth rate of agriculture recorded negative growths in 1978, 1981-82, 1984-85 and 1988 with average growth of $1.3 \%$ during the pre-reform period due to unfavorable agro-ecological climate and unstable political situation. After 1992 there was the positive growth of agriculture observed in the country with maximum growth of $16.9 \%$ in 2004 and lowest value of $-10.8 \%$ in 2003 . On average $4.8 \%$ of agricultural growth recorded.

As we can see in the figure, industrial sector showed an increasing trend. The large decline in industrial growth observed from 1975 to 1978 and from 1988 to 1992 as result of a socialized economic system that discouraged private sector involvement in the industry sector. However, after economic reform, there was slightly continuous increasing trend showed in industry sector up to 2002 which was not as expected. Since 2003, government massive engagement in social and infrastructure development intended to increase industrial output growth more than previous slow growth. During this period on average 13.6\% growth is recorded from 2003 to 2016 as compared to $6 \%$ after economic reform took place. The substantial growth in the industrial sector is as a result of various incentives by government to attract private participation in industry sector with side by side improvement in efficiency and effectiveness of government-owned industries.

Regarding the trend of service sector output growth as shown in above figure 4.4, Average annual real GDP growth of the sector increased from $1.3 \%$ during the 1980 s to over $9.5 \%$ in the period from 1992 to $2015 / 16$. The growth of service sector is experienced some of ups and downs fluctuating from positive to negative growth during the pre-reform period. In between 1975 and 1992, the real GDP growth rate of agriculture recorded negative growths in 1977-78, 1984, 1989 and 1991-92 with average growth of 1.3\% during the pre-reform period. After 1992, full of study period there is the continuous and positive growth of service sector observed in the country with maximum growth of $17 \%$ in 2004 and lowest value of $3.3 \%$ in 2003 . 
Figure 5. Trend of agricultural, industrial and service sectors growth

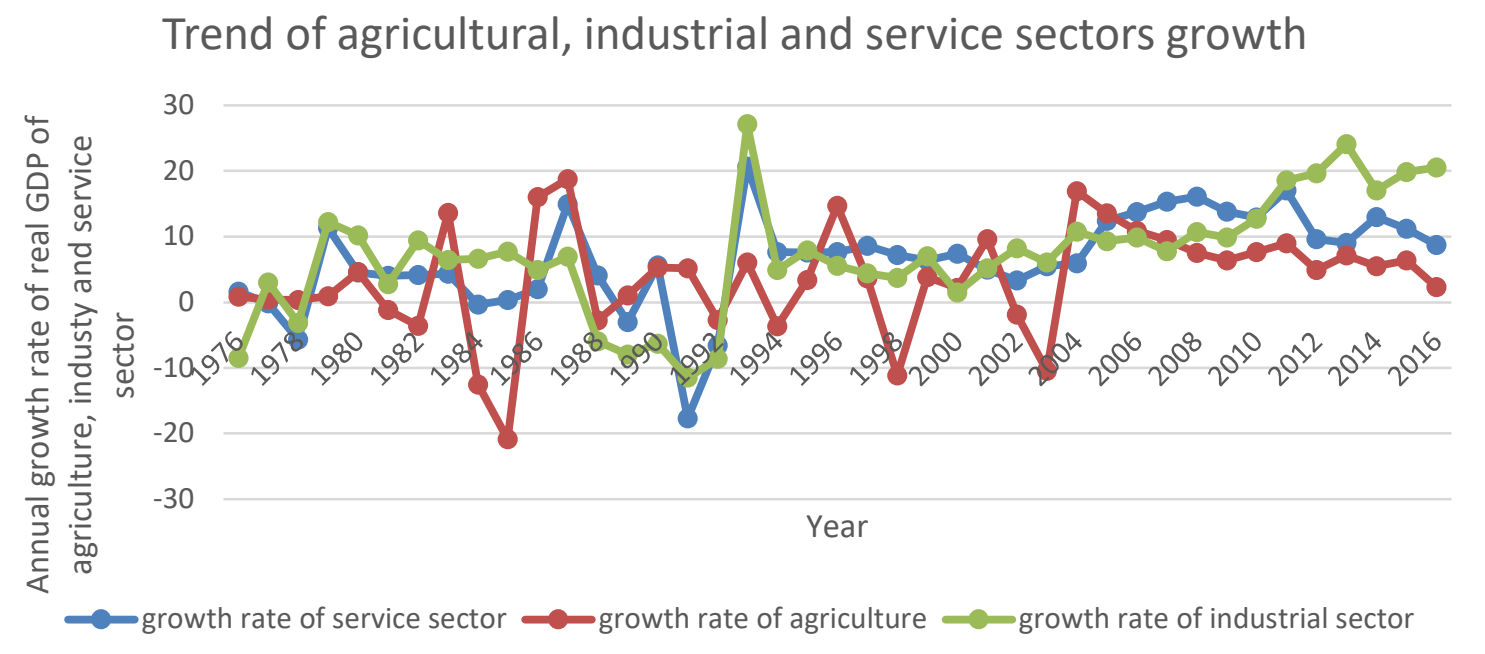

Source: author computation from national bank of Ethiopia abstracts and MOFEC data

Figure 4.5 also shows the contribution of agriculture, manufacturing and service sectors to the overall growth. During the periods of $1975-1992$, on average $68.8 \%$ of the overall growth was contributed by the agriculture sector. The manufacturing sector contributed $9.8 \%$ of the growth and the service sector contributed $31.2 \%$. This shows that slow increment on service sector share made the overall growth to be positive while agricultural sector share indicates declining trend. The larger share in the growth fluctuation was attributed to the poor performance of agriculture because of drought and instability. In between 1993- 2016, However, on average the service sector has contributed increasingly and agricultural sector decreasingly contribute to economic growth while until implementation of Growth and Transformation plan I, industry sector showed a slow trend in contribution to economic growth. The average contribution of agriculture to the total economy growth was just $51.8 \%$, the industry and the service sector contributed $10.7 \%$ and $39.5 \%$ of the growth respectively. The large contribution of the agricultural sector in Ethiopia history was overtaken service sector since 2011. Specifically, the share of agricultural value added in GDP has declined by about 10 percentage points between 1990 and 2016 (from 63 to 36 percent; see Figure 4.5). In response to these trends, the Ethiopian government, as part of its Growth and Transformation Plan II, has focused on both rapid industrialization and structural transformation.

Generally, even though there is strong policy emphasis on agriculture, its contribution to overall growth has been not only limited but also declining: declined from 56\% in 2000/1 to $36 \%$ in 2015/16. The growth contribution of the manufacturing has remained minimal. The service sector continued to be the main engine of growth of the economy, accounting for $47 \%$ of the growth of overall GDP in 2015/16.

Figure 6. Sectoral growth contribution to overall growth

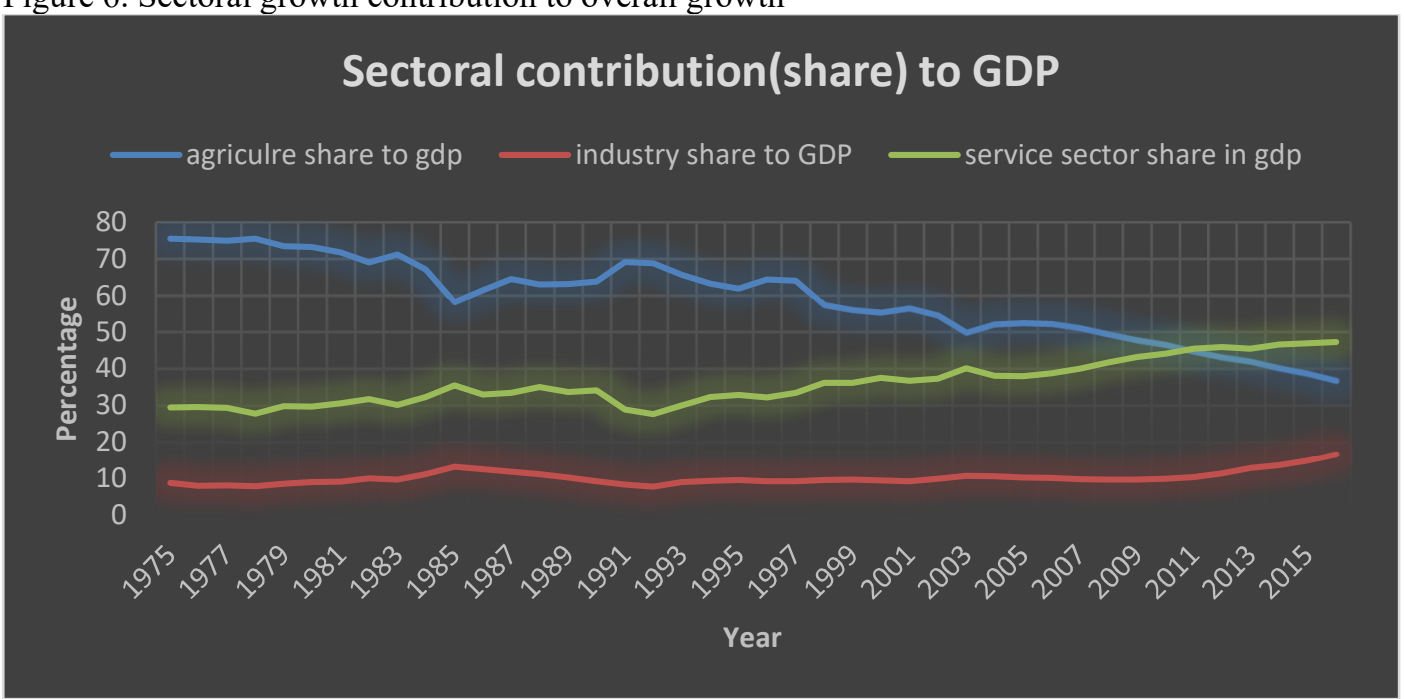

Source: author computation from national bank of Ethiopia abstracts and MOFEC data

The implication of changes in the growth contributions from the main sector is changing in the structure of the economy occurring across sectors, from agriculture to service and industry. According to the study of Yared 
et. al. (2015), Crop production, traditionally a dominant contributor, has been overwhelmed by construction and wholesale and retail trade sub-sectors. The increase in the industrial sector's contribution to growth especially first phase of GTP has largely originated in the construction sub-sector. He also pointed out that note that the more productive manufacturing sector has not grown enough to contribute to sustainable growth.

\section{CONCLUSIONS}

Financial sector development affects sectoral output growth through efficient mobilization of saving for investment, allocation of resources to productive activities, reducing risks, generation of liquidity, and trade facilitation, monitoring entities and enforcement of corporate governance.

Bank credit to agriculture, industry, and service sectors have to be given high attention so as to boost investment and thereby reduce foreign borrowing. Commercial banks are providing a negligible amount of loan to the agricultural sector as compared to another remaining sector while the large contribution of GDP comes from agriculture next to service sector. Therefore, the government should give priority to agricultural sector through making access to adequate credit for productive activities to enhance modernization of agricultural production. In Growth and Transformation Plan II, industry mainly manufacturing sector in Ethiopia play the major role in structural transformation in the country. To achieve the desired objective, the government should strengthen its current effort on development of financial sector to support industrial sector in the country.

In order to enhance the development financial sector, the policy makers should focus long run policies mainly improving financial markets so as to make the efficient and effective allocation of resources among productive sector which affects long-run sectoral output growth. On another word, in order to promote economic growth, it is important to improve banking function and competition by liberalizing the banking sector and promotion of private banks in Ethiopia.

\section{Bibliography}

Addison, Tony and Alemayehu, Geda, 2001. Ethiopia's New Financial Secto rand Its Regulation. Discussion Paper No. 2001/55, pp. 1-20.

Assefa, D., 2003. A Review of the Performance of Agricultural Finance in Ethiopia: Preand Post Reform Periods. s.l.:s.n.

D. Sebina, M. K. „Sukumaran Nair and M. Rathedi, 2014. 3. The Causal Relationship Between Financial Development And Economic Growth: Does Inflation Matter? Empirical Evidence from Botswana,. Asian- African Journal of Economics and Econometrics vol. 14, No. 2, pp. 259-27

Ellahi, N., 2011. How development of finance contributes to poverty alleviation and growth: A time series application for Pakistan. African Journal of Business Management Vol.5 (30), pp. 12138-12143, 30 November, 2011, pp. 12138-12143.

Ethiopia, N. B. o., 2015. annual reports, s.1.: s.n.

Fozia, M., 2014. The Nexus between Economic Growth and Financial Development: The Case of Ethiopian Economy. Addis Ababa University, Ethiopia, s.n., pp. 23-52.

Roman, T., 2012. the link between financial development and economic growth in Ethiopia, Adis Abeba: unpublished Masters thesis.

Wondaferahu, M., 2010. The Structure and Development of Ethiopia's Financial sector. Andhra University: India. Yared, Seid, Alemayehu, Seyoum T. and Seid, Nuru Ali, 2015. Ethiopia - an agrarian economy in transition. WIDER Working Paper 2015/154. 
Appendix I: Loans \& Advances by EconomicSectors

\begin{tabular}{|c|c|c|c|c|c|c|c|c|c|}
\hline \multirow[t]{3}{*}{ Economic Sectors } & \multicolumn{3}{|l|}{$2014 / 15$} & \multicolumn{3}{|l|}{$2015 / 16$} & \multicolumn{3}{|c|}{ Percentage Change } \\
\hline & $\mathrm{D}^{*}$ & $\mathrm{C}^{*}$ & $\mathrm{O} / \mathrm{S}^{*}$ & $\mathrm{D}^{*}$ & $\mathrm{C}^{*}$ & $\mathrm{O} / \mathrm{S}^{*}$ & $\mathrm{D}^{*}$ & $\mathrm{C}^{*}$ & $\mathrm{O} / \mathrm{S}^{*}$ \\
\hline & $\mathrm{A}$ & B & $\mathrm{C}$ & $\mathrm{D}$ & $E$ & $\mathrm{~F}$ & $\mathrm{D} / \mathrm{A}$ & $\mathrm{E} / \mathrm{B}$ & $\mathrm{F} / \mathrm{C}$ \\
\hline Agriculture & $13,077.10$ & $11,456.20$ & $18,579.80$ & $13,375.70$ & $12,863.40$ & $20,377.50$ & 2.3 & 12.3 & 9.7 \\
\hline Industry & $23,437.40$ & $11,782.90$ & $86,212.30$ & $25,495.60$ & $15,954.10$ & $106,164.00$ & 8.8 & 35.4 & 23.1 \\
\hline Domestic Trade & $15,589.00$ & $12,183.20$ & $25,336.40$ & $15,040.50$ & $15,297.70$ & $28,550.60$ & -3.5 & 25.6 & 12.7 \\
\hline International Trade & $8,415.00$ & $11,790.80$ & $43,303.90$ & $9,528.00$ & $15,707.90$ & $51,900.40$ & 13.2 & 33.2 & 19.9 \\
\hline Export & $3,780.40$ & $5,587.30$ & $17,581.30$ & $4,404.90$ & $8,429.60$ & $23,028.40$ & 16.5 & 50.9 & 31 \\
\hline import & $4,634.60$ & $6,203.50$ & $25,722.60$ & $5,123.10$ & $7,278.30$ & $28,872.00$ & 10.5 & 17.3 & 12.2 \\
\hline Hotels and Tourism & $1,620.30$ & $1,510.90$ & $3,590.60$ & $1,893.80$ & $2,406.50$ & $4,818.80$ & 16.9 & 59.3 & 34.2 \\
\hline $\begin{array}{ll}\text { Transport } & \text { and } \\
\text { Communication } & \\
\end{array}$ & $3,625.50$ & $2,340.60$ & $7,289.00$ & $4,494.10$ & $3,336.80$ & $10,026.10$ & 24 & 42.6 & 37.6 \\
\hline $\begin{array}{ll}\text { Housing } & \text { and } \\
\text { Construction } & \\
\end{array}$ & $6,720.10$ & $7,040.40$ & $22,529.10$ & $13,641.90$ & $8,422.30$ & $28,080.80$ & 103 & 19.6 & 24.6 \\
\hline $\begin{array}{l}\text { Mines, Power and } \\
\text { Water resource }\end{array}$ & 165.2 & 83.4 & 844.7 & 341.2 & 145.5 & 851.8 & 106.5 & 74.4 & 0.8 \\
\hline Others & $2,163.80$ & $1,449.80$ & $7,827.70$ & $3,160.80$ & $2,393.90$ & $10,297.70$ & 46.1 & 65.1 & 31.6 \\
\hline Personal & 667.5 & 363.4 & $1,796.90$ & $1,051.40$ & 652.9 & $2,779.60$ & 57.5 & 79.7 & 54.7 \\
\hline Interbank Lending & - & 12.66 & 57.8 & - & 5.72 & 54.3 & - & -54.8 & -6.2 \\
\hline Total & $83,895.90$ & $71,805.06$ & $260,672.10$ & $97,551.00$ & $92,894.62$ & $315,802.00$ & & & \\
\hline
\end{tabular}

Source: National Bank of Ethiopia Annual Abstract 2016

$\mathrm{D}^{*}=$ Disbursement, $\mathrm{C}^{*}=$ Collection, $\mathrm{O} / \mathrm{S} *=$ Outstanding Credit

Appendix A: Capital and Branch Network of the Banking System at the Close of June 30, 2016

\begin{tabular}{|c|c|c|c|c|c|c|c|c|c|c|c|c|}
\hline \multirow[t]{3}{*}{ Banks } & \multicolumn{8}{|c|}{ Branch Network } & \multicolumn{4}{|c|}{ Capital(in million birr) } \\
\hline & \multicolumn{4}{|c|}{$2014 / 15$} & \multicolumn{4}{|c|}{$2015 / 2016$} & \multicolumn{2}{|c|}{$2014 / 15$} & \multicolumn{2}{|l|}{$2015 / 2016$} \\
\hline & Regions & $\begin{array}{l}\text { Addis } \\
\text { Ababa }\end{array}$ & Total & $\begin{array}{l}\% \\
\text { Share }\end{array}$ & Regions & $\begin{array}{l}\text { Addis } \\
\text { Ababa }\end{array}$ & Total & $\begin{array}{l}\% \\
\text { Share }\end{array}$ & $\begin{array}{l}\text { Total } \\
\text { Capital } \\
\end{array}$ & $\begin{array}{l}\% \\
\text { Share }\end{array}$ & $\begin{array}{l}\text { Total } \\
\text { Capital } \\
\end{array}$ & $\begin{array}{l}\% \\
\text { Share }\end{array}$ \\
\hline $\begin{array}{l}\text { Commercial } \\
\text { Bank of } \\
\text { Ethiopia }\end{array}$ & 785 & 192 & 977 & 36 & 888 & 262 & 1150 & 36.1 & $10,716.40$ & 34.8 & $13,557.50$ & 31.5 \\
\hline $\begin{array}{l}\text { Construction } \\
\& \text { Business } \\
\text { Bank }\end{array}$ & 69 & 51 & 120 & 4.5 & 0 & 0 & 0 & 0 & - & - & & 0 \\
\hline $\begin{array}{l}\text { Development } \\
\text { Bank of } \\
\text { Ethiopia }\end{array}$ & 31 & 1 & 32 & 1.2 & 106 & 4 & 110 & 3.5 & $2,269.20$ & 7.4 & $7,500.80$ & 17.4 \\
\hline $\begin{array}{l}\text { Total Public } \\
\text { Banks }\end{array}$ & 885 & 244 & 1129 & 42 & 994 & 266 & 1260 & 39.5 & $12,985.50$ & 42.1 & $21,058.30$ & 48.9 \\
\hline $\begin{array}{l}\text { Total Private } \\
\text { Banks }\end{array}$ & 851 & 713 & $1,564.00$ & 58 & $1,096.00$ & 831 & $1,927.00$ & 60.5 & $17,822.80$ & 57.9 & $22,002.50$ & 51.1 \\
\hline $\begin{array}{l}\text {.Grand Total } \\
\text { Banks }\end{array}$ & 1736 & 957 & 2693 & 100 & $2,090.00$ & 1097 & 3187 & 100 & $30,808.30$ & 100 & $43,060.80$ & 100 \\
\hline
\end{tabular}

Source: National Bank of Ethiopia Annual Abstract -2016 
Appendix B: Loans \& Advances by EconomicSectors

\begin{tabular}{|c|c|c|c|c|c|c|c|c|c|}
\hline \multirow[t]{3}{*}{ Economic Sectors } & \multicolumn{3}{|l|}{$2014 / 15$} & \multicolumn{3}{|l|}{$2015 / 16$} & \multicolumn{3}{|c|}{ Percentage Change } \\
\hline & $\mathrm{D}^{*}$ & $\mathrm{C}^{*}$ & $\mathrm{O} / \mathrm{S}^{*}$ & $\mathrm{D}^{*}$ & $\mathrm{C}^{*}$ & $\mathrm{O} / \mathrm{S}^{*}$ & $\mathrm{D}^{*}$ & $\mathrm{C}^{*}$ & $\mathrm{O} / \mathrm{S}^{*}$ \\
\hline & $\mathrm{A}$ & $\mathrm{B}$ & $\mathrm{C}$ & $\bar{D}$ & $E$ & $\bar{F}$ & $\mathrm{D} / \mathrm{A}$ & $\mathrm{E} / \mathrm{B}$ & $\mathrm{F} / \mathrm{C}$ \\
\hline Agriculture & $13,077.10$ & $11,456.20$ & $18,579.80$ & $13,375.70$ & $12,863.40$ & $20,377.50$ & 2.3 & 12.3 & 9.7 \\
\hline Industry & $23,437.40$ & $11,782.90$ & $86,212.30$ & $25,495.60$ & $15,954.10$ & $106,164.00$ & 8.8 & 35.4 & 23.1 \\
\hline Domestic Trade & $15,589.00$ & $12,183.20$ & $25,336.40$ & $15,040.50$ & $15,297.70$ & $28,550.60$ & -3.5 & 25.6 & 12.7 \\
\hline International Trade & $8,415.00$ & $11,790.80$ & $43,303.90$ & $9,528.00$ & $15,707.90$ & $51,900.40$ & 13.2 & 33.2 & 19.9 \\
\hline Export & $3,780.40$ & $5,587.30$ & $17,581.30$ & $4,404.90$ & $8,429.60$ & $23,028.40$ & 16.5 & 50.9 & 31 \\
\hline import & $4,634.60$ & $6,203.50$ & $25,722.60$ & $5,123.10$ & $7,278.30$ & $28,872.00$ & 10.5 & 17.3 & 12.2 \\
\hline Hotels and Tourism & $1,620.30$ & $1,510.90$ & $3,590.60$ & $1,893.80$ & $2,406.50$ & $4,818.80$ & 16.9 & 59.3 & 34.2 \\
\hline $\begin{array}{l}\text { Transport and } \\
\text { Communication }\end{array}$ & $3,625.50$ & $2,340.60$ & $7,289.00$ & $4,494.10$ & $3,336.80$ & $10,026.10$ & 24 & 42.6 & 37.6 \\
\hline $\begin{array}{ll}\text { Housing } & \text { and } \\
\text { Construction } & \\
\end{array}$ & $6,720.10$ & $7,040.40$ & $22,529.10$ & $13,641.90$ & $8,422.30$ & $28,080.80$ & 103 & 19.6 & 24.6 \\
\hline $\begin{array}{l}\text { Mines, Power and } \\
\text { Water resource }\end{array}$ & 165.2 & 83.4 & 844.7 & 341.2 & 145.5 & 851.8 & 106.5 & 74.4 & 0.8 \\
\hline Others & $2,163.80$ & $1,449.80$ & $7,827.70$ & $3,160.80$ & $2,393.90$ & $10,297.70$ & 46.1 & 65.1 & 31.6 \\
\hline Personal & 667.5 & 363.4 & $1,796.90$ & $1,051.40$ & 652.9 & $2,779.60$ & 57.5 & 79.7 & 54.7 \\
\hline Interbank Lending & - & 12.66 & 57.8 & - & 5.72 & 54.3 & - & $\begin{array}{l}- \\
54.8\end{array}$ & -6.2 \\
\hline Total & $83,895.90$ & $71,805.06$ & $260,672.10$ & $97,551.00$ & $92,894.62$ & $315,802.00$ & & & \\
\hline
\end{tabular}

Source: National Bank of Ethiopia Annual Abstract 2016

$\mathrm{D}^{*}=$ Disbursement, $\mathrm{C}^{*}=$ Collection, $\mathrm{O} / \mathrm{S}^{*}=$ Outstanding Credit

Appendix B: Capital and Branch Network of the Banking System at the Close of June 30, 2016

\begin{tabular}{|c|c|c|c|c|c|c|c|c|c|c|c|c|}
\hline \multirow[t]{3}{*}{ Banks } & \multicolumn{8}{|c|}{ Branch Network } & \multicolumn{4}{|c|}{ Capital(in million birr) } \\
\hline & \multicolumn{4}{|c|}{$2014 / 15$} & \multicolumn{4}{|c|}{$2015 / 2016$} & \multicolumn{2}{|c|}{$2014 / 15$} & \multicolumn{2}{|l|}{$2015 / 2016$} \\
\hline & Regions & $\begin{array}{l}\text { Addis } \\
\text { Ababa }\end{array}$ & Total & $\begin{array}{l}\% \\
\text { Share } \\
\end{array}$ & Regions & $\begin{array}{l}\text { Addis } \\
\text { Ababa } \\
\end{array}$ & Total & $\begin{array}{l}\% \\
\text { Share } \\
\end{array}$ & $\begin{array}{l}\text { Total } \\
\text { Capital } \\
\end{array}$ & $\begin{array}{l}\% \\
\text { Share } \\
\end{array}$ & $\begin{array}{l}\text { Total } \\
\text { Capital } \\
\end{array}$ & $\begin{array}{l}\% \\
\text { Share } \\
\end{array}$ \\
\hline $\begin{array}{l}\text { Commercial } \\
\text { Bank of } \\
\text { Ethiopia }\end{array}$ & 785 & 192 & 977 & 36 & 888 & 262 & 1150 & 36.1 & $10,716.40$ & 34.8 & $13,557.50$ & 31.5 \\
\hline $\begin{array}{l}\text { Construction } \\
\& \text { Business } \\
\text { Bank }\end{array}$ & 69 & 51 & 120 & 4.5 & 0 & 0 & 0 & 0 & - & - & & 0 \\
\hline $\begin{array}{l}\text { Development } \\
\text { Bank of } \\
\text { Ethiopia } \\
\end{array}$ & 31 & 1 & 32 & 1.2 & 106 & 4 & 110 & 3.5 & $2,269.20$ & 7.4 & $7,500.80$ & 17.4 \\
\hline $\begin{array}{l}\text { Total Public } \\
\text { Banks }\end{array}$ & 885 & 244 & 1129 & 42 & 994 & 266 & 1260 & 39.5 & $12,985.50$ & 42.1 & $21,058.30$ & 48.9 \\
\hline $\begin{array}{l}\text { Total Private } \\
\text { Banks }\end{array}$ & 851 & 713 & $1,564.00$ & 58 & $1,096.00$ & 831 & $1,927.00$ & 60.5 & $17,822.80$ & 57.9 & $22,002.50$ & 51.1 \\
\hline $\begin{array}{l}\text { Grand Total } \\
\text { Banks }\end{array}$ & 1736 & 957 & 2693 & 100 & $2,090.00$ & 1097 & 3187 & 100 & $30,808.30$ & 100 & $43,060.80$ & 100 \\
\hline
\end{tabular}

Source: National Bank of Ethiopia Annual Abstract -2016 